Vol. 4, No. 1, January 2016

Jurnal llmial

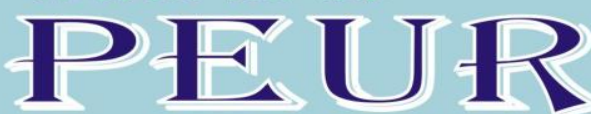

Media Kajian Ilmiah Sosial, Politik, Hukum, Agama dan Budaya
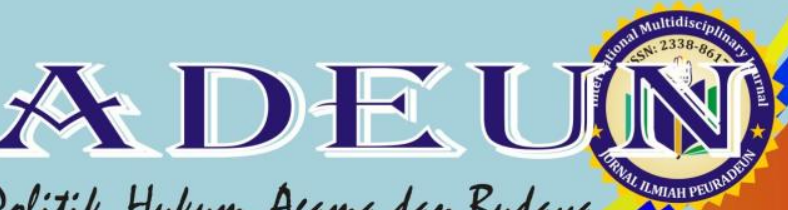


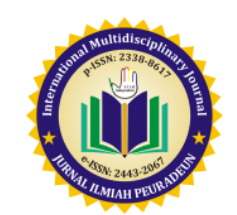

\title{
TRANSMIGRATION, MULTICULTURALISM AND ITS RELATIONSHIP TO CULTURAL DIVERSITY IN EUROPE
}

\author{
${ }^{1}$ Christian Grililo La Torre and ${ }^{2}$ Katerine Francesca Montalto \\ ${ }^{1}$ Department of Cultural Studies, University of Rijeka, Rijeka, Croatia \\ Email: la_torre@yahoo.com, Phone: +385 51416503 \\ ${ }^{2}$ Department of Humanities, University of Catania, Catania, Italy \\ E-mail: francisca_mt@gmail.com
}

Received: May 13, 2015

Accepted: July 23, 2015

Published: Jan 21, 2016

Article Url: https://journal.scadindependent.org/index.php/jipeuradeun/article/view/84

\begin{abstract}
All European societies are ethnically and culturally plural. Historically, the most significant source of cultural (not necessarily synonymous with ethnic) diversity in European nationstates has been regional, often a result of conjoining economically, socially, culturally, linguistically - and indeed ethnically - disparate places into single polities, and (certainly in Northern and Western Europe) engaging them in what the French call nationalization. This paper discusses the relationship between cultural diversity in Europe, and that international movement described as "transnational" (transmigration). Though not as new or as homogeneous as some have proposed, transmigration will grow in importance in the $21 s t$ century. Groups or individuals may return to places of origin or "assimilate" into receiving societies, but without resort to unacceptable levels of control of the movement of people, goods and ideas, transmigration will be a prominent structural feature of European societies for the foreseeable future: do we really wish to monitor every exchange between receiving and sending societies? In any case, modern systems of communication (e.g. the Internet), and the cheapness and rapidity of mass international travel make such surveillance difficult, even impossible in a transnational, globalizes world.
\end{abstract}

Keywords: Transmigration, Transnational, Multiculturalism, Cultural Diversity, Europe 


\section{A. Introduction}

Historically, most migrants to the countries of Europe (often from within Europe itself, moving South-North or East-West) settled in those countries, abandoned all but symbolic ties with places of origin, became citizens of their new homes, and took on the local culture, values and language. Even then, however, some were transmigrant, living across borders. Transmigration is not new, but much more widespread and persistent because of swifter and cheaper means of international travel and communication, the flexibility and uncertainty of contemporary job markets, precarious tenure in the receiving society, racism and xenophobia which migrants face each day, the inability to live lives and bring up children in accordance with strongly held religious, moral and social beliefs, the relative cost of living after retirement etc. etc. Undoubtedly some will stay on, assimilating, in the classic sense. Many others will engage in a contested integration seeking to create more private and public ethnic and cultural space in the receiving society. For others, transmigration will be a permanent way of life, at worst as a transnational sub proletariat, at best (not to be despised) with dual citizenship or citizenship in one place and secure denizen ship in another.

Transmigration and cultural diversity are related dialectically. Ethnic and cultural pluralism in Europe (including philosophies of integration and institutional mechanisms for implementing policies of what is usually called multiculturalism) shape, and are shaped by, transmigration in its various guises; transmigration shapes and is shaped by the institutional structuring of cultural diversity in European receiving societies and transmigrants experience of it. In investigating this relationship, I identify various transmigration "scenarios", and begin to explore their implications for cultural policies and regimes of rights and obligations (Castles and Davidson 2000).

All European societies are ethnically and culturally plural. Historically, the most significant source of cultural (not necessarily synonymous with ethnic) diversity in European nation-states has been regional, often a result of conjoining economically, socially, culturally, linguistically - and indeed ethnically - disparate places into single polities, and (certainly in Northern and Western Europe) engaging them in what the French call nationalization. One model of the 
contemporary construction of Europe, at any rate a European Union, perhaps seeks to replicate that process at a supra-national level. However and increasingly since World War II, another source of difference has been the large-scale movement of populations across what became national boundaries, seeking work and/or refuge. Just as nation-states originally sought to nationalize their regions, so too they attempted to assimilate (or reject) immigrants and refugees.

\section{B. Culture and Cultural Diversity}

There is much to be said for distinguishing between these two sources of difference (Kymlicka's contrast, 1995: 10-11, between "multination" and "polyethnic" states), though many European countries experience both, and peoples such as Jews, Roma and African Americans in the USA do not readily fit with either. The two are not, of course, separate. Their interconnection needs to be understood, and there is also much to be learned about one from the other. For example, what recent migration studies have told us about the nature of culture in a transnational world has great relevance for views of culture(s) traditionally found in discussions of ethno-regionalism. Although many of the participants in the Symposium were primarily concerned with the first, particularly the connection between culture and territory, this paper concentrates on the second which has been of great import in Northern Europe since at least the 1960s, and is now of increasing significance throughout the continent. (It is sometimes difficult to transcend the pre-conceptions and preoccupations, nightmares even. of one's own country. In Britain - as opposed to Spain? - regionalism is mainly economic and political and only weakly cultural: Scottish nationalism is more concerned with oil than language. What preoccupies people in Britain from a cultural point of view is the perceived threat from Europe, i.e. "Brussels", on the one hand, and immigrants/ refugees/ ethnic minorities on the other, especially when Muslim. Is it that the world looks different from the point of view of Catalonia?).

Favell (1999) has argued that European states are not "nations of immigrants" like the USA, Canada or Australia, where "indigenous" populations are minute and dwarfed (where not exterminated) by voluntary or forced migrants from elsewhere. Nonetheless, in France, Germany and the UK there are several million persons, $5 \%-10 \%$ of the population, who are first, 
second and even third generation migrants and refugees. In other countries with long-standing immigrant populations (e.g. Belgium, Holland, Sweden), numbers are smaller, but proportionately no less. In these, and in places which previously thought of themselves as countries of emigration (e.g. Italy, Greece, Spain), new or continuing inflows of migrants and refugees, population growth among existing (settled) immigrants, plus intermarriage (increasingly important in the UK and elsewhere), has heightened ethnic and cultural diversity, most markedly in the residential quarters and employment sectors of the major cities, where for economic and other reasons these populations tend to be concentrated. Migrants, moreover, have an important, indeed iconic status in Europe because from Portugal to Norway, from the UK to Austria their presence has been politicized, and is increasingly prominent on political agendas across the spectrum. Even if not a continent of immigrants, like the Americas, Europe is a place in which immigrants and their descendants play an important economic, social, cultural and political role.

The discussion of "cultural diversity" in this context encounters a number of complications, indeed the very notion has to be seen as trebly problematic. First, the emphasis on national integration (e.g. 'turning peasants into Frenchmen', Weber 1976), means that historically contemporary nation states have had, and continue to have, great difficulties with difference. In much of Europe, as Blommaert and Verschueren point out in their account of the diversity debate in Belgium, 'an homogeneous community is regarded as the norm, and diversity is only acceptable to the extent that it does not touch social harmony as viewed by the majority' (1998: 81) Though (see below), there has across Europe in recent years been a shift towards greater acceptance of the legitimacy of regional and ethnic (immigrant) minority difference - under certain conditions - for many people cultural, ethnic, and "racial" otherness continue to be a threat and a challenge, and multiculturalism, where it exists, a constant site of struggle.

Let me interject a brief comment on religion which interestingly was mentioned only sporadically at the Symposium. Historically religion would have been a very important (some would have said the most important) source of diversity in a Europe divided into a Catholic South, a Protestant North, and an Orthodox East, with a Jewish (and now Muslim) Europe scattered throughout but generally concentrated in the major cities. (This "map" is a 
caricature, but let that pass). In the past, of course, such differences were of enormous importance, and still are in certain places (e.g. Ulster.) Their omission from our discussion perhaps reflects the sense we have that in most European societies religion and state are firmly separated. Constitutionally this is not true of the UK, but by and large we live in a secular Europe in which religion, if it has a place at all, is firmly in the private domain. Yet religion cannot be kept entirely out of the picture of cultural diversity. Even though religious practice continues its decline in most of Europe, for some people religion remains a very strong source of culture, and religious leaders continue to exercise a powerful influence: consider, for example, the pronouncements of Biffi, Cardinal Archbishop of Bologna, who in September 2000 called for the closure of mosques, and for the Italian government to admit only Catholic immigrants. Moreover, religion appears to be reclaiming public space (e.g. in the USA), and cannot yet be written out of the European equation. Finally, even if religious practice is in permanent decline, and the power and influence of religious leaders on the wane (e.g. the position of the Catholic Church in the Republic of Ireland), the way in which religion has shaped cultural perceptions over a very long period needs detailed consideration. There may still be a protestant and a catholic Europe (lower case " $\mathrm{p}$ " and " $\mathrm{c}$ "), even if Protestantism and Catholicism are not the forces they once were.

The reference to religion, especially to Islam, leads us to the second problem: the relationship between perceived cultural difference and xenophobia (e.g. "Islamophobia".) In the 1980s there was much discussion in academic circles in Britain and France of a "new racism." Since it was no longer possible openly to employ classic forms of racial discrimination and abuse, the language of cultural difference became a coded way of speaking about "race", a disguised form of "real" racism (for discussion and references see inter alia Stolcke 1995, Grillo 1998.) Undoubtedly this is sometimes the case, but I agree with Stolcke (1995) that cultural hostility is also something sui generis. Stolcke (1995: 2-12) identifies the rise of a 'rhetoric of exclusion and inclusion that emphasizes the distinctiveness of cultural identity, traditions, and heritage among groups and assumes the closure of culture by territory'. This discourse of "cultural fundamentalism", as she calls it (Amselle, 1998), 'rather than asserting different endowments of human races', emphasizes the incommensurability of cultures 
and assumes that relations between them are "by "nature" hostile'. Though 'hostility against extra communitarian immigrants may have racist overtones, and metaphors can certainly be mixed', the 'contemporary rhetoric of exclusion', she continues, 'thematizes ... relations between cultures by reifying cultural boundaries and difference'. This view is also associated with an essentialism (see below and Grillo 1998a) in which individual and collective identity is rooted in culture, and readily leads to what I call "cultural conservationism", a mode of thinking (present in many forms of multiculturalism) in which cultures are conceived as static, bounded entities whose authenticity must be preserved (or invented), and protected, like rare species.

In commenting on Stolcke's paper, Terence Turner rightly observes that cultural fundamentalism is not confined to right-wing xenophobes: 'an often equally fundamentalist multiculturalism is becoming the preferred idiom in which minority ethnic and racial groups are asserting their right to a full and equal role in the same societies' (in Stolcke 1995: 17.)

This leads to a third point. Both majorities and minorities frequently express anxiety about cultural change and cultural power. We see this historically in the opposition by regional minority intellectuals influenced by Romanticism (e.g. Mistral's Félibrige, with its dream of a resurrected Latin culture and society) who rallied to Herder's call: "National cultures, where are you?", in contemporary concerns (e.g. in the UK) about the influence of Europe and/or the United States and/or the arrival of immigrants with different cultural traditions, as well as among migrants worried about their children's loss of the religious and cultural values they brought with them. Underlying such anxiety is a static view of culture and society in which the principal communities (which define peoples and their identities) are "ethnic" (and territorial), and ethnic communities have attached to them "cultures" which are under threat from other communities with other cultures, and should be preserved. This may be contrasted with the more dynamic view (widely held in contemporary academic anthropology, if not in the "real world"), that cultures and communities are socio-historically (and politically) constructed (dialectically from above and below), and in constant flux. The paradox of transmigration is that it both stimulates cultural anxiety and conservationism and questions its static assumptions. 


\section{Transmigration and globalisation}

Contrary to what was predicted in the 1970s, international migration did not slacken, but intensified, with ever greater numbers of migrants and refugees drawn from an ever-increasing range sending societies seeking entry to an ever-widening range of countries of reception. It has been suggested, however, that whereas past migrants settled in the countries of reception, in this "new age of migration" (Castles and Miller 1998), they retain significant, continuing ties with countries of origin. During the 1990s scholars based mainly in the USA (e.g. Glick Schiller et al eds. 1992, Basch et al 1994, Rouse 1992, Smith 1998, Smith and Guarnizo eds. 1998) used "transnationalism" for this type of international migration ("transmigration"). To emphasize the emergence of a social process in which migrants establish social fields that cross geographic, cultural, and political borders. Immigrants are understood to be transmigrants when they develop and maintain multiple relations - familial, economic, social, organizational, religious, and political - that span borders (Glick Schiller et al. 1992: ix).

Transmigration entails manifold socio-economic, political and cultural linkages across boundaries, raises questions about identity (and identification), and rights and entitlements, and problematical 'bounded conceptualizations of race, class, ethnicity, and nationalism [we should add culture] which pervade both social science and popular thinking' (Glick Schiller et al. 1992: x).

Over the past decade there has been much debate about whether, and if so how, contemporary transmigration is a new phenomenon, about its causes, its various forms, and long-term trajectories. Anyone with knowledge of international migration over the past century is bound to have a sense of déjà vu when reading about transmigration (Grillo, 1998b). Certainly, the literature on circular labour migration in colonial and post-colonial Africa dealt extensively with what would now be called "transmigration", and political and economic activities straddling two or more countries is not new: Irish Republicanism, Jewish Zionism, and the Italian Mafia offer three very different examples of migrants and their descendants engaged in transnational social, economic and political linkages continuously since the 19th century. Even so, I agree with Smith (1999: 3) that such migrations were 'not theorized as [transnational] they were rarely analyzed as being systematically related, and as producing new and 
interesting outcomes at both sites.' Thus, Joan Mira (this volume) rightly observes that migration from southern to northern Europe in the period 1950-70 was also transnational, and raises interesting questions concerning comparison between that and more recent experience. But those questions would not have been asked without a lead from the transnational perspective.

Some discussions have tended to blur a distinction between transnationalism and globalization; that is one reason I prefer "transmigration", which better signals my specific topic. There is, however, what I call a "strong", political economy version of transmigration wherein globalizations is the context within which contemporary movement must be understood. The globalizations of production, distribution and exchange (banking, stock markets, debt, the division of labor, mass international transportation systems, new communication technologies, the media etc. etc) has been accompanied by new forms of international organization. Post-1973 there has also been a global political and economic shift in which Northern economies, then those of developing countries, and after 1989, those of the former socialist world, underwent major restructuring. A "Washington consensus" around neoliberal economic and financial principles replaced the postWorld War II "Keynesian consensus"; "Fordism" gave way to "Postfordism" and flexible, deregulated working arrangements where people scrape together a living from multiple income-earning opportunities. In the North, especially, changes in the occupational base and a progressive disintegration of forms of social and political organization associated with modernity led to the apparent displacement of class from centre stage, and the emergence of "new" social movements, many of them transnational, based on gender, sexuality, regional, ethnic or religious identity, or special interest e.g. environmentalism (Appadurai 1996: 23.)

Above all, economic and political insecurity do not allow migrants to commit themselves to long-term residence in the country of reception. Taking the case of Aguilillan (Mexican) migration to California, Rouse (1992: 26) criticisms former views of migration as movement between independent communities, and settlement 'as a process in which people steadily shift their focus of attention and the locus of their principal social ties from one community to another'. Economic restructuring in Mexico has made it impossible for Aguilillans to fulfill goals of developing small family businesses locally, and their main source of income is from international migration. But the restructuring and polarization of 
employment within the US means few opportunities for advancement in the economy of reception. Thus Aguilillans are trapped within what Rouse (1992: 45) calls a 'transnational migrant circuit'; they are 'a transnational semi proletariat, caught chronically astride borders and class positions'.

Migration, then, has been increasing globally due to economic restructuring which is making everywhere insecure. Racism in the US and Europe add to that insecurity, and transmigration is both a consequence and an attempt to come to terms with this. This is not, of course, the whole story. For example, much refugee movement cannot be understood within this framework, and demographic pressures in both sending and receiving societies have a part to play. In Italy, an ageing population and increasing tendency for women to seek employment outside the home mean that there are demands for domestic service workers which can only be met by immigration. Indeed, the large scale international movement of female domestic and "caring" service workers is a striking feature of contemporary transnational migration. There is a gender dimension here which needs careful consideration.

Thus many European states contain migrants and refugees, some long resident, others recent arrivals, who (to greater or lesser degrees, and in different ways, and not uniformly within them) have a multiple orientation: to the receiving society where they may be citizens and in which they may be resident, and to another place with which they maintain economic, political, familial, religious and linguistic ties, and which may be conceived of as "home." That orientation may be dual (cf. the South Asian phrase Desh Pardesh, Home from Home"), or triple in that populations from "home" may be spread across several countries or continents, and transnational diasporas may themselves become communities of orientation. (Like others I have reservations about the way all migrations are now "diasporas". "Diaspora" stakes a political claim for recognition of a particular kind).

At the same time, many receiving countries have, especially since the 1960s, moved away from policies seeking to assimilate immigrants (e.g. "Americanization"), and to greater or lesser degrees made room for difference, along the lines of the British policy of "integration" as set out (rather complacently) in the so-called "Jenkins formula" of 1966, (see in Jenkins, 1967: 267). 


\section{Transmigration Trajectories}

A criticism of the literature on transmigration is that it sometimes assumes a homogeneous entity, e.g. undifferentiated as to gender. It also sometimes assumes that current practices and linkages will be maintained by future generations, when it is controversial whether transmigration is a long term or transitional phenomenon, with migrants eventually loosening transnational ties, and settling in the country of immigration. Take, for instance, two groups currently important in Italian immigration which provide a relevant contrast. Senegalese live and work in Italy leaving wives and children in Senegal. Many more Moroccans live as couples with children, though more women than is supposed originally arrived as single workers. Moroccan families in Italy are steadily increasing, while Senegalese family reunions remain exceptional. From this it can be anticipated that Moroccan and Senegalese experience of living in Italy will be very different, as will demands on the health and educational services, the range of Italian "intercultural" and other professionals (housing officers, teachers, nurses, trade union officials) with whom they interact, and the "problems", as they will be seen, for integration and multiculturalism. Yet both are transmigrants.

For the Senegalese, this means engaging in economic transactions across international boundaries, and over considerable distance, spending much of their time away from home, but returning there at frequent intervals with the goal of creating an economic, social and spiritual life for themselves and their families in Senegal (Riccio, 1999). Moroccans too maintain strong ties with their region of origin, and have traditionally done so, but modern methods of communication 'enable migrants to rely on two countries to construct their social personhood by distributing not only economic but also symbolic resources' (Salih, 1999: 88.) They have two homes - Morocco, Italy. Domestic space in Italy is constructed in ways which display Moroccan roots, while homes in Morocco reflect an Italian reference. This might be interpreted as the best of both worlds, though the way of life is not necessarily sustainable: decisions about what must happen to children or in old age are critical in this regard, and as Salih (1999: 102) points out the 'dual belonging allowed by transnationalism is also cause of a sense of rupture and discontinuity for women.' Whereas Senegalese migrants in Italy are (for the time being) oriented towards an ultimate return to Senegal, Moroccans manifest (also for the time 
being) a dual orientation. Both Senegalese and Moroccans are "here and there" (Italy and Senegal/Morocco) but in different ways.

A recent report on the future of multi-ethnic Britain (Parekh Report, 2000), much criticized in the press, argued for a view of Britain as a "community of communities." Reading the Report suggests a tension in this idea, which seems to imply a collectivity of ethnically and culturally distinct groups. Yet this interpretation is at odds with a statement which the Report itself cites, with approval, of an informant from Bradford:

I could view myself as a member of the following communities, depending on the context and in no particular order: Black, Asian, Azad Kashmiri, Mirpuri, Jat, Marilail, Kungrieslay, Pakistani, English, British, Yorkshireman, Bradfordian, from Bradford Moore ... I could use the term "community" in any of these contexts and it would have meaning. Any attempt to define me only as one of these would be meaningless (Parekh Report, 2000: Section 4.17).

(Interestingly he does not include "European" or "Muslim"). The Report implies that on the one hand there are "English", "Pakistani" or "Mirpuri" communities, on the other individuals, like this informant, who see themselves belonging to a multiplicity of such "communities", and whose identity relates in a complex (and evolving) way to all of them. To suggest that Britain, as "community of communities", consists of a finite set of such entities (themselves finite and bounded), and that these define homogeneous individual identities, is to fall into the trap of essentialism and reification, to classify human beings as cultural (and in one version national, territorial) subjects, bearers of a culture located within a boundaries world, which defines them and differentiates them from others. By contrast, the Ottomans defined persons as religious subjects by reference to their scriptural traditions (as Muslims, Jews, Orthodox, "Armenians" and Latin's.) The Ottomans employed religions of the book we employ "cultures".

\section{E. Conclusion}

We must accept that cultural processes always occur within a framework of political and economic power. We must also ensure that in "multiculturalism" we are not simply institutionalizing a particular anthropology, meaning vision of humanity and of the human subject, in which communities are conceived as ethnic communities, with cultures attached, and rights to recognition as such, and that this vision instructs us how we 
can/should cope with difference. Otherwise, cultural fundamentalism, essentialism, reification, and stereotyping, along with cultural conservationism, will remain persistent players in the management of diversity, and the underlying anthropology of place, territory, culture, which informed the construction of nation-states, will continue to guide the incorporation of immigrants and ethnic minorities in the construction of Europe.

In the last two centuries, however, European nation-states have been based on notions of cultural essentialism and policies of nationalization and assimilation. Neither such policies, nor the conservationist reaction to which they give rise, make allowance for the intersection of the local and the global in the production of cultural identity in a contemporary transnational world in which societies have (once again) become 'porous'. Porous boundaries and multiple identities undermine ideas of cultural belonging as a necessary accompaniment to political membership.

Transnational ties may not be entirely absent under conditions of assimilation, and may well form part of (indeed reinforce) systems of essentialist multiculturalism. But under certain conditions transmigration becomes one vector through which that essentialism, which has been integral to the hitherto prevailing system of nation-states, breaks down, replaced by more complex networks and identities of a diasporic, cross-over character. At the same time this process may generate precisely that reaction which I term cultural anxiety. We should not fear change or give way to that anxiety. Essentialism, conservationism and their political instantiations seek to block the 'infinite process of identity construction' which is ethnicity. Globalization and transnationalism have opened the Pandora's Box of cultural essentialism.

\section{Bibliography}

Amselle, J.-L. (1998). Mestizo logics: anthropology of identity in Africa and elsewhere. Stanford: Stanford University Press.

Appadurai, A. (1996). Modernity at large: Cultural dimensions of globalization. Minneapolis: University of Minnesota Press.

Castles, S. and Davidson, A. (2000). Citizenship and migration: globalization and the politics of belonging. London: Macmillan. 
Favell, A. (1999). Integration policy and integration research in Europe: a review and critique. Report prepared for the Carnegie Endowment Comparative Citizenship Project.

Glick Schiller, N., Basch, L. and Blanc-Szanton, C. (1992a). "Towards a definition of 'transnationalism': Introductory remarks and research questions", pp. ix-xiv of Glick Schiller, N., Basch, L. and BlancSzanton, C. (eds.) Towards a transnational perspective on migration. New York: New York Academy of Sciences.

Grillo, R.D. (1998a). Pluralism and the politics of difference: State, culture, and ethnicity in comparative perspective. Oxford: Clarendon Press.

Grillo, R.D. (1998b). “Transnational (see also postnational)"? Paper Presented to the Social Anthropology Graduate/Faculty Seminar, University of Sussex, 1 October 1998.

Jenkins, R. (1967). Essays and speeches. London: Collins.

Karibi, R. A. I. N. (2015). Religion, Human Rights and the Challenges of Freedom. Jurnal Ilmiah Peuradeun, 3(1), 39-54.

Kearney, M. (1995). “The local and the global: the anthropology of globalization and transnationalism". Annual Review of Anthropology. 24: 547-65.

Kymlicka, W. (1995). Multicultural citizenship: a theory of liberal rights. Oxford: Clarendon Press.

Lvina, E. (2015). The Role of Cross-Cultural Communication Competence: Effective Transformational Leadership Across Cultures. Jurnal Ilmiah Peuradeun, 3(1), 1-18.

Parekh Report (2000). The future of multi-ethnic Britain (Runnymede Trust). London: Profile Books.

Rex, J. (1996). Ethnic minorities in the modern nation state. London: Macmillan.

Riccio, B. (1999). Senegalese transmigrants and the construction of immigration in Emilia-Romagna (Italy). DPhil Thesis. University of Sussex.

Rogers, R. (1986). "The transnational nexus of migration". Annals of the American Academy of Political and Social Science. 485: 34-50.

Rouse, R. (1992). "Making sense of settlement: class transformation, cultural struggle and transnationalism among Mexican migrants in the United States", pp. 25-52 of Glick Schiller, N., Basch, L. and Blanc-Szanton, C. (eds.) Towards a transnational perspective on migration. New York: New York Academy of Sciences. 
Rouse, R. (1995). “Thinking through transnationalism: notes on the cultural politics of class relations in the contemporary United States". Public Culture. 7(2): 353-402.

Salih, R. (1999a). Transnational lives, plurinational subjects: Identity, Migration and Difference among Moroccan women in Italy. DPhil Thesis. University of Sussex

Smith, M.P. and Guarnizo, L.E. (eds.) (1998). Transnationalism from below. New Brunswick: Transaction Publishers.

Smith, R. (1998). Changing practices of citizenship, membership and nation within the context of transnational migration: Comparative insights from the Mexican and Italian cases. Paper presented to ICCCR International Conference on Transnationalism, Manchester, 16th-18th May 1998.

Smith, R. (1999). Comparing local level Swedish and Mexican transnational life: an essay in historical retrieval. Unpublished paper.

Stolcke, V. (1995). "Talking culture: new boundaries, new rhetorics of exclusion in Europe". Current Anthropology. 36(1): 1-24.

Weber, E. (1976). Peasants into Frenchmen: the modernization of rural France 1870-1914. London: Chatto and Windus.

ZA, T. (2014). Islamic Studies dalam Pendekatan Multidisipliner (Suatu Kajian Gradual Menuju Paradigma Global). Jurnal Ilmiah Peuradeun, 2(2), 211-234. 